Research, part of a Special Feature on Resilience and Vulnerability of Arid and Semi-Arid Social Ecological Systems

\title{
Anticipating Vulnerability to Climate Change in Dryland Pastoral Systems: Using Dynamic Systems Models for the Kalahari
}

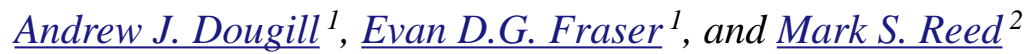

\begin{abstract}
It is vitally important to identify agroecosystems that may cease functioning because of changing climate or land degradation. However, identifying such systems is confounded on both conceptual and methodological grounds, especially in systems that are moving toward thresholds, a common trait of dryland environments. This study explores these challenges by analyzing how a range of external pressures affect the vulnerability of dryland pastoral systems in the Kalahari. This is achieved by employing dynamic systems modeling approaches to understand the pathways by which communities became vulnerable to drought. Specifically, we evaluate how external pressures have changed: (1) different agroecosystems' abilities to tolerate drought, i.e., ecosystem resilience; (2) rural communities' abilities to adapt to drought, mediated via their access to assets; and (3) the ability of institutions and policy interventions to play a role in mediating drought-related crises, i.e., socio-political governance. This is done by reanalyzing ecological and participatory research findings along with farm-scale livestock offtake data from across the Kalahari in Botswana. An iterative process was followed to establish narratives exploring how external drivers led to changes in agroecosystem resilience, access to assets, and the institutional capacity to buffer the system. We use "causal loop diagrams" and statistical dynamic system models to express key quantitative relationships and establish future scenarios to help define where uncertainties lie by showing where the system is most sensitive to change. We highlight how that greater sharing of land management knowledge and practices between private and communal land managers can provide 'win-win-win' benefits of reducing system vulnerability, increasing economic income, and building social capital. We use future scenario analyses to identify key areas for future studies of climate change adaptation across the Kalahari.
\end{abstract}

Key Words: Botswana; climate change; drought sensitivity; dynamic systems modelling; Kalahari; pastoral farming; vulnerability pathways

\section{INTRODUCTION}

The purpose of this study is to apply dynamic system modeling tools to investigate food system vulnerability to both climate change and land degradation, with a focus on drought sensitivity in the pastoral Kalahari region of Botswana. We draw on published data and field ecological and participatory research findings to generalize factors that influence how the agroecosystem responds to drought. These factors are linked to key components of the pastoral system using a dynamic systems model, which explores a series of quantifiable future scenarios. This paper's empirical contribution is to develop and provide a detailed analysis of the pastoral system to answer two key research questions: (1) Is there evidence that the Kalahari pastoral-based food system is becoming more or less vulnerable to drought?; and (2) What policy "leverage points" are there to reduce vulnerability in this dynamic agroecosystem?

We also make a theoretical contribution by providing a case study to evaluate the strengths and weaknesses of using quantitative dynamic systems modeling to assess dryland pastoral system vulnerability. To date, livelihoods research in this region on this issue has been based primarily on field-based research (e.g., Sporton and Thomas 2002, Chanda et al. 2003, Rohde et al. 2006, Reed et al. 2008, Sallu et al. 2009). Quantitative modeling that links socioeconomic and biological factors has 
not been attempted. This case is interesting more broadly as it focuses on a pastoral system, typical of many of the most climatically marginal African drylands that have always suffered recurring droughts and food shortages (Lane 1997), but are often ignored in development debates that focus on food security in terms of crop production (e.g., Parry et al. 1999, FAO 2006, IPCC 2007). Furthermore, pastoral societies across dryland Africa face a range of changes in their farming systems and thus present difficult research, management, and policy challenges (Reynolds et al. 2007). This is partly because of land tenure reform that has undermined traditional livestock management (Toulmin and Quan 2000), as well as increased rainfall variability over the last 50 years across Southern Africa (Tennant and Hewitson 2002) and sub-Saharan Africa more widely. Therefore, both the academic literature (e.g., Warren 2002, Reynolds et al. 2007) and the global policy statements via the United Nations Convention to Combat Desertification (UNCCD) now recognize the need for integrated research, based on global change and sustainability science, to provide more policy- and developmentrelevant outputs for drylands. However, the specifics of how this is best achieved in case study regions remains largely unexplored.

\section{RESEARCH DESIGN AND METHODS}

We significantly extend previous field-based studies from this region by developing and applying a four-stage dynamic systems modeling exercise in which we reinterpret data and interview information from a decade of multidisciplinary research. Work involves four methodological steps taking us from the initial integration of local and scientific knowledge all the way to a quantitative vulnerability analysis capable of modeling different proposed management, market, and policy options under two future climate scenarios. The outline methods are:

1. We use expert opinion, derived from researchers who have worked on ecological and socioeconomic studies across the region for more then 15 years to develop conceptual models of agroecosystem functioning. This was combined with a reanalysis of land-user interview transcripts to establish a background narrative that describes the livelihoods system and its social, institutional, and ecological context.
2. We use economic livestock data from a local, i.e., ranch or village, level to refine the narrative and establish the conceptual model of the system, focusing on three dimensions of vulnerability: agroecological, household assets, and institutional factors (Fraser 2007).

3. We then conduct a qualitative vulnerability analysis of this system by using the narrative and the conceptual model to show how these three dimensions of vulnerability have changed through time.

4. We conduct a quantitative vulnerability analysis by expressing key relations in the conceptual model mathematically using VENSIM, a software tool for dynamic systems modeling. We run different management, market, and policy simulations to examine how the model is sensitive to assumptions made in developing the conceptual model. This leads us to establish a series of hypotheses about which system elements are most influential in changing future vulnerability.

The final quantitative step in this process entails making assumptions about the nature and strength of relations. We explicitly discuss the value of this key aspect of the study, and its potential problems, in our analysis and in the discussion.

\section{BACKGROUND NARRATIVE}

Lying in the semiarid interior of Southern Africa, approximately $80 \%$ of Botswana is covered with Kalahari sand soils and savanna ecosystems that support both commercial and communal livestock systems, as well as National Park and Wildlife Management Areas. The climate is typified by a mean annual rainfall varying from less than $200 \mathrm{~mm}$ p.a. in the South-West to $650 \mathrm{~mm}$ p.a. in the NorthEast with an interannual variability of c. $40 \%$ (Bhalotra 1987). Despite significant economic growth based largely on diamonds, $47 \%$ of Botswana's population lives under the UN's two US dollars/day poverty line (CIA 2009). In Botswana, pastoral agriculture represents the chief source of livelihood for more then $40 \%$ of the nation's 1.8 million residents (FAO 2006), and cattle represent an important source of status and 
well-being for the vast majority of Kalahari residents (White 1993). Beef sales constitute c. 5\% of national exports and $1.5 \%$ of GDP (Hitchcock 2002).

The food production and livelihood system of the Kalahari remains predominantly a pastoral one. These savanna ecosystems are utilized for both cattle and smallstock, mainly goats and sheep, in proportions dependent on the land tenure system, $i$. e., communal or private, and on the environmental characteristics of forage availability, notably the ratio of bush to grass and the availability of palatable grass species. Traditional systems are transhumant, with a high degree of herd mobility to respond to the patchy nature of rainfall and forage (Sporton and Thomas 2002) with c. 70\% of the country still under customary communal land tenure (Clover and Eriksen 2009). These systems have been constrained in places by fencing and privatization of large areas supported by a series of national agricultural policies and international trade agreements that provide tariff-free access to international markets for beef, the EU in this case, dependent on disease control measures. As such, private-owned ranch farming systems have developed that are increasingly sedentary and commercialized with former communal rangeland being privatized and fenced. This has led to absentee owners who employ a few local residents to manage their land and livestock (Adams et al. 2002), and is restricting the land available to communal systems that support residents of settlements across the Kalahari where few other livelihood options exist (Ringrose et al. 1996, Hitchcock 2002). Rural poverty, AIDS-HIV, and growth in the mining and urban economies have also led to a decline in rural labor and farming as a way of life (Twyman et al. 2004).

Within pastoral Kalahari systems, ecological resources and their dynamics are critically important for livelihoods (Sallu et al. 2009). In terms of food provision, the reliance on livestock means that milk and meat are important for daily diets, often supplemented by wild fruits. It also means that there is a heavy reliance on food imports, notably maize meal, with some millet and sorghum, that are staple foods despite there being only limited production of these crops. This cereal production is itself threatened by climatic changes (Chipanshi et al. 2003) and soil degradation (Dougill et al. 2002), therefore maize meal is predominantly imported from South Africa and sold in local markets, or provided in lieu of cash for labor by wealthy land owners. In times of drought, which is designated most years by the Government of Botswana, jobs are offered by government to enable families to earn wages for maize purchase. This offers a safety net that has thus far minimized the numbers of droughtinduced cases of famine and malnutrition in Botswana.

Real concerns exist over the dual threats of poverty and land degradation as they increase the vulnerability of pastoral communities to environmental change (Thomas and Twyman 2004) and reduce the resilience of the rangeland ecosystem (Thomas et al. 2000). In some parts of Botswana, land degradation has led to extensive areas of thorny bush encroachment, which cannot be accessed by cattle (Moleele et al. 2002), reducing the economic returns from rangelands. In the drier southwest of Botswana, land degradation has also led to the mobilization of dune fields (Reed et al. 2008). Pastoralists use a wide range of indicators to recognize and monitor land degradation processes, most of which are supported by empirical ecological assessments (Reed et al. 2008). For example:

Staying in an area too long is like wearing the same dress for years; it gets worn out. Female communal farmer, age 65.

\section{The veld (rangeland) is like a person: there are fat and thin people and no matter how much you feed some people, they remain thin. If the soil is poor, no matter how much it rains, nothing will grow. Male communal farmer, age 82 .}

The National Action Programme to Combat Desertification (Botswana Department of Environmental Affairs 2006) has been drafted and approved as required for inclusion in the UNCCD and associated funding negotiations. However, many uncertainties remain on the accuracy and legitimacy of this report because of its emphasis on soil erosion. It is questionable given the weight of environmental research focusing on ecological change and the lack of in-depth participatory consultation at the village level. There is also uncertainty on how best to implement policies aimed at providing environmental and food system resilience at a local and district level, as per broader discussions across Southern Africa (Stringer et al. 2007). These uncertainties 
mean the policy needs greater guidance to help reduce agroecosystem vulnerability. It is to this end that the stages in this research are guided.

\section{BUILDING OF CONCEPTUAL MODEL}

The building of the conceptual model was initially undertaken by one of the authors with no research experience in the study region to avoid subjective bias in analysis of expert interviews. A series of 12 one-on-one interviews were held with the two authors who have worked extensively across the study region and who have previously published ecological conceptual models of the rangeland system (Dougill et al. 1999, Dougill 2002, Reed et al. 2008). These interviews developed a more holistic conceptual model of the farming system and identified socioeconomic, environmental, and political driving forces for change, drawing on both ecological research outputs and interviews undertaken with pastoralists, extension workers, and policy-makers. The authors' field experience focuses on: the Kgalagadi District, around Bokspits, Tsabong, and Tshane; Central District, Makoba Ranch Block; and Ghanzi District, Ncojane Ranch Block. Thus the model presented is viewed as applicable to these Kalahari rangeland systems (Fig. $1)$. Indeed, we stress that studies conducted further north in Mopane woodland and pan systems of the mid-Boteti District find significantly different indicators of degradation (Reed et al. 2008).

Following these interviews, an expert workshop involving eight participants, who have all worked in semiarid livelihoods systems, was held in which the conceptual model was presented, discussed, and refined. Finally, further refinements were undertaken following interviews with six researchers and policy makers with extensive research experience from the region, including staff from the Government of Botswana. The first interviews were semistructured to identify major drivers and outputs. Subsequent interviews and the workshop were designed to develop and refine the conceptual model and included discussions of institutional, social, and ecological subsystems. Over a period of eight months and 15 iterations, the background narrative was turned into a dynamic systems model flow chart (Fig. 2) that identifies the feedback loops and highlights indicators of vulnerability that are assessed in subsequent qualitative and quantitative analyses.

\section{QUALITATIVE STAGES OF MODEL BUILDING}

\section{Part I: Changes in capacity of the agroecosystem to remain productive in drought}

In terms of the capacity of the agroecosystem to remain productive during a drought (variables inside circles in Fig. 2), a number of major environmental changes suggest that the region is losing some of its agroecological resilience:

- Reduction in the cover of perennial, i.e., palatable, grass species and their replacement by annual, i.e., less palatable, grasses (Thomas et al. 2000);

- Increase in the proportion of thorny bush cover spreading over wide areas because of fire suppression and the maintenance of intensive grazing through droughts (Dougill et al. 1999);

- Increased spatial heterogeneity and patchiness of key soil nutrients (N \& P) linked to landscape-scale grazing patterns and associations of microbial soil crusts with encroaching bush species (Berkeley et al. 2005);

- Climate variability remains high, though as yet it is hard to associate any definitive changes in farming practices or yields caused directly by global-scale climate change processes (Washington et al. 2005);

- Borehole water depths are increasing and in the more arid areas, e.g., Southwest Botswana near Bokspits, very little or no potable water is currently found. In addition, there are concerns that ancient stable dune systems will become active here (Thomas et al. 2005).

These changes threaten agroecosystem resilience because of the reliance on livestock as the dominant income source for supporting livelihoods. The loss of perennial and palatable grass species has a direct impact on the size and viability of cattle-keeping and has, in many areas, led to a significant shift to the keeping of sheep and goats as the main livelihood activity (Rohde et al. 2006, Sallu et al. 2009). In a few commercial, privately owned ranches, a shift has been made to farm game species, e.g., springbok, gemsbok, and ostrich, though this 
Fig. 1. Location of research sites upon which expert knowledge and farmer interviews are based.

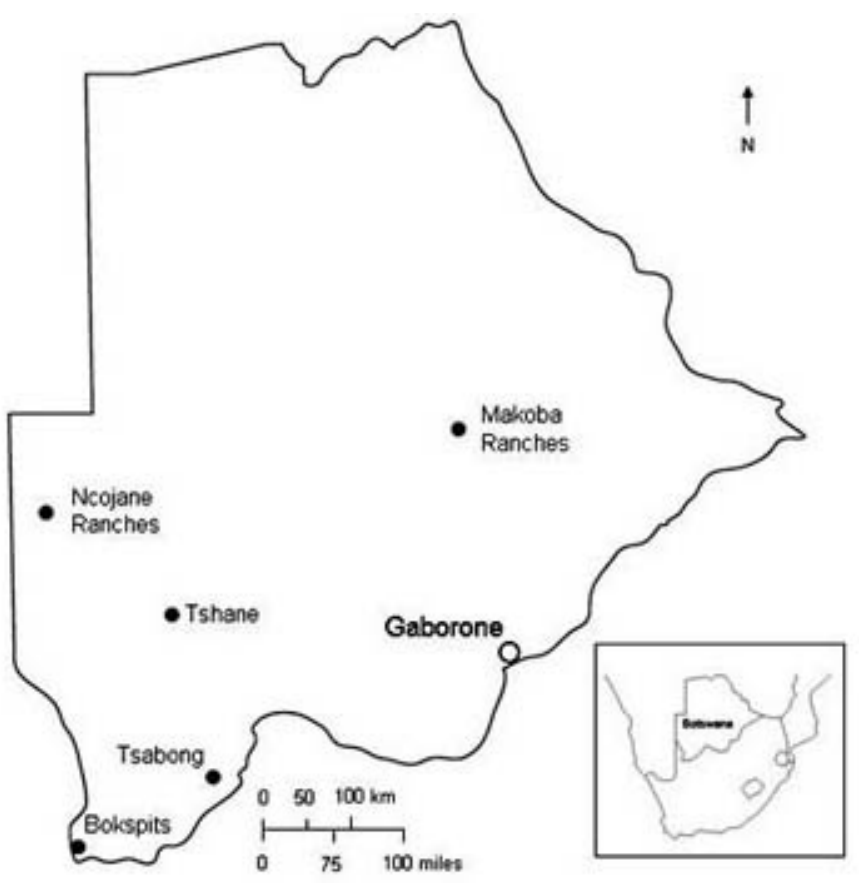

is not widespread compared to that in South Africa (Milton et al. 2003) and Namibia (McGranahan 2008). In areas where thorn bush stands extend over many kilometers, or tens of kilometers as around Kgalagadi District settlements (Chanda et al. 2003), forage availability and diversity is reduced to the extent that traditional pastoral systems become vulnerable and non-natural resource based livelihood options become vital. In these areas, residents are seeking alternative livelihood options, sometimes migrating to urban centers, or they depend on government support, e.g., pensions and drought relief assistance, with rangelands no longer being the major source of livelihood for many residents (Chanda et al. 2003). The existence of these support systems and improved access to regional markets mean that rural communities remain in the Kalahari. However, they are increasingly vulnerable to environmental changes, whether ecological or climatic, and it is recognized that current policy arrangements are inadequate (Stringer et al. 2007) given projected climatic changes.

\section{Part II: Changes in capacity of individuals to adapt to drought}

In terms of the capacity of individuals to adapt (variables inside squares in Fig. 2) to droughts, communities across the Kalahari span a range of ethnic groups, principally Tswana, Herero, and Basarwa/San, as well as cultural and socioeconomic histories and characteristics (Sporton and Thomas 2002). This makes it difficult to generalize the nature of a socioeconomic 'community structure,' with many now stressing that dynamics within a community need to be considered more explicitly (e.g., Twyman et al. 2002, Sallu et al. 2009). The largest single ethnic group are the Tswana who first introduced cattle into the Kalahari more then 2,000 years ago and now make up the majority of Botswana's population (Hitchcock 2002). Indigenous tribal groups, e.g., the Basarwa/San, have been working in cattle-keeping societies for many centuries, and the populist image of isolated bushmen as pristine historical artifacts living a hunting-gatherer existence is a misrepresentation of complex interdependent systems. What has developed is a hierarchy with Tswana political 
Fig. 2. Dynamic systems model of the agropastoral food system of southern Botswana. Each variable in this model emerged from expert opinions, and the sign next to each arrow (+ or -) indicates whether the relation is positive or negative as classed from interviews and/or available data analysis.

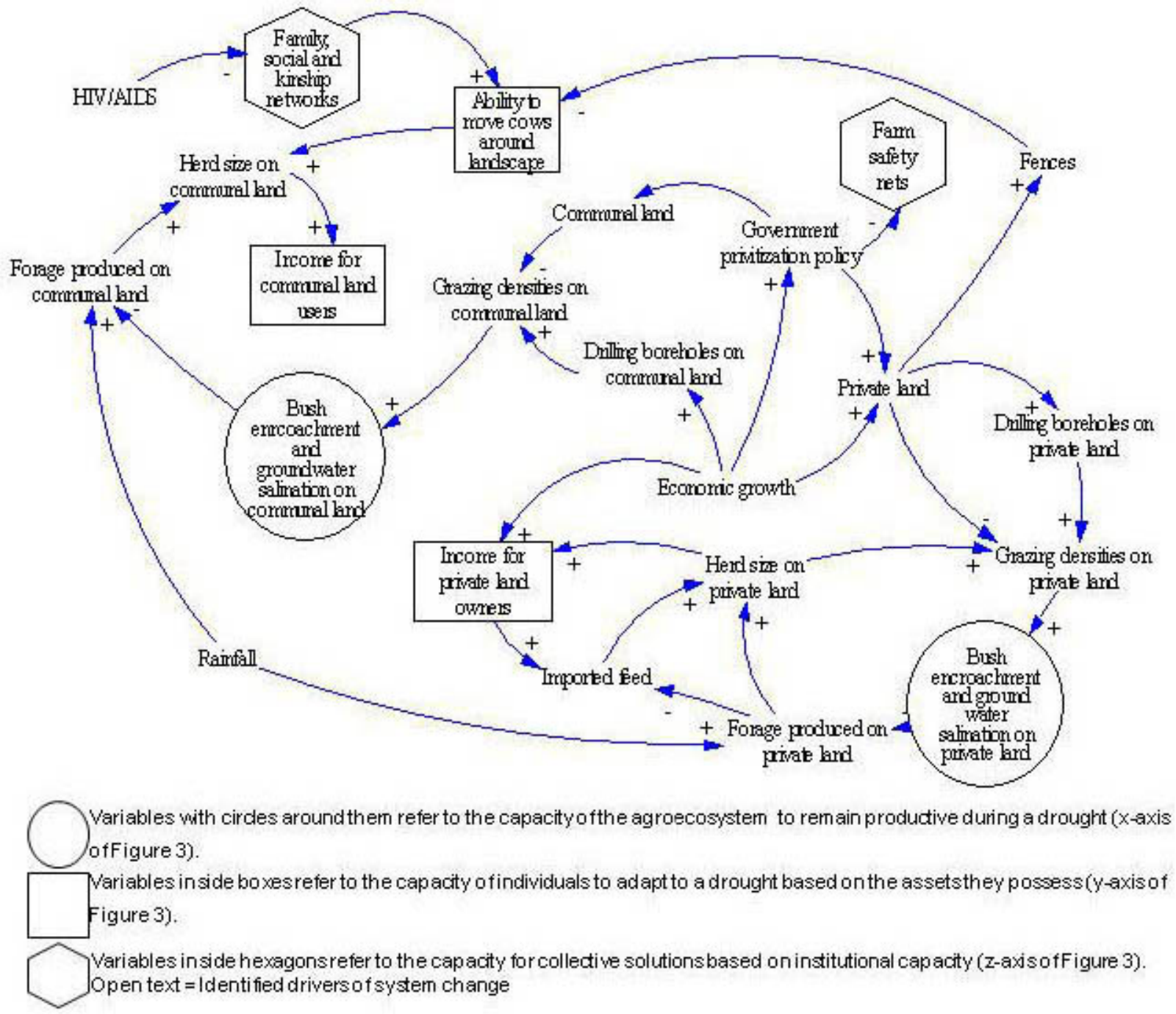

dominance despite international campaigns to restore some land and power to indigenous groups.

Tswana society is itself hierarchical and cattlekeeping is culturally important. Strong community structures exist through tribal chiefs and elders who make up village courts (kgotla). The power of traditional community systems has declined as greater influence is felt from national and districtlevel government structures, dominated by the main
Tswana political party, i.e., the Botswana Democracy Party (BDP), that has ruled Botswana since independence in 1966. In both Tswana and Herero households, livestock is an important source of capital, being saved for key events such as weddings, funerals, and paying school fees, as well as having value from milk and meat in the food system. It is normal that the majority of households own some animals, even if this is only a small number of sheep or goats. Indeed, recent 
government programs have provided support for smallstock rearing as a route to help poorer households through times of drought.

With increasing national wealth, there is a growing divide between rich and poor. International measures show that Namibia, South Africa, and Botswana have the most iniquitous distribution of wealth of any countries calculated by the Gini index (CIA 2009). This divide drives increasing pressures for private land ownership. Within individual villages, this has marginalized women, the young, and Basarwa tribal groups (Hitchcock 2002). Both out-migration from rural areas and increased mortality rates because of the HIV-AIDS pandemic are also affecting rural community structures. Many societies are dealing with a lack of fit, working-age people, leaving grandparents to run households with young children and significant numbers of orphans. The strength of extended family and ethnic groups remains a strong binding agent. However, with outmigration this is threatened and could reduce system resilience associated with the ability to move livestock across an area, which is also curtailed by disease related controls. Physical capital is increased through government provision of infrastructure, i.e., roads, health centers, etc., as is the human capital through the enhanced knowledge base provided by free primary schooling, although this reduces access to labor. This means that for many people, especially those without livestock, a decline in access to financial capital is the real problem in securing adequate food supplies, and is leading to an increasing reliance on government support (Sallu et al. 2009) and/or overseas aid (Rohde et al. 2006).

\section{Part III: Changes in the collective capacity to respond to drought}

The collective capacity of pastoral communities to respond to droughts (variables inside hexagons in Fig. 2) is based on the nature and effectiveness of formal or informal institutions, including social networks (Twyman et al. 2002). In this regard, land is either communally owned and managed through traditional tribal systems at a village scale, or privately owned by individuals or syndicates (Adams et al. 2002). Within both systems, there is strong national control of livestock sales through the Botswana Meat Commission (BMC), a parastate organization that controls more then $90 \%$ of the nation's cattle, and livestock movement through controls on the provision of borehole water sources. The single parastatal set-up of the BMC offers the potential for government to help establish emergency livestock marketing interventions, or to buy livestock rapidly at the onset of droughts. However as yet, no such coordinated actions have been undertaken by the BMC.

Throughout the late twentieth century, there has been a move away from traditional tribal and village institutional systems (Sporton and Thomas 2002). This move away from local decision making and control is now recognized as a regional problem (Rohde et al.2006). As such, mechanisms are slowly being put in place to support traditional systems and to bridge government assistance, e.g., from agricultural extension workers, with local traditional systems. Given that droughts tend to occur at a district or national scale, the greater role of district and national institutions offers a better capacity to respond.

\section{Link to vulnerability assessment models}

Based on literature review and interview reanalysis, there are two broad vulnerability pathways (Fig. 3) through the vulnerability space as developed by Fraser (2007). The first path is for the "wealthy" private ranchers who have lost out in terms of ecological resilience, but gained in terms of collective and individual capacity to respond to a drought. The other pathway is for the "poorer" communal pastoralists who have seen their vulnerability increase in all three dimensions (Fig. 3).

\section{QUANTITATIVE VULNERABILITY ASSESSMENTS}

\section{Part I: Expressing relations mathematically}

To assess how policy effects vulnerability to drought in the Kalahari, we revisited and analyzed the interview insights from participatory research to mathematically express the relations in the conceptual model. Given the system complexity and the limited empirical research on relationships recording and explaining yields / livestock production, it is as yet impossible to use quantitative methods to test relationships and establish sophisticated linear or polynomial relations that can 
Fig. 3. Heuristic depiction of changing levels of vulnerability to drought for southern Botswana pastoralists over the past 30 years. T1, T2, and T3 refers to wealthy ranchers who raise cattle on private land. T1', T2' and T3' refer to poorer pastoralists on communal land.

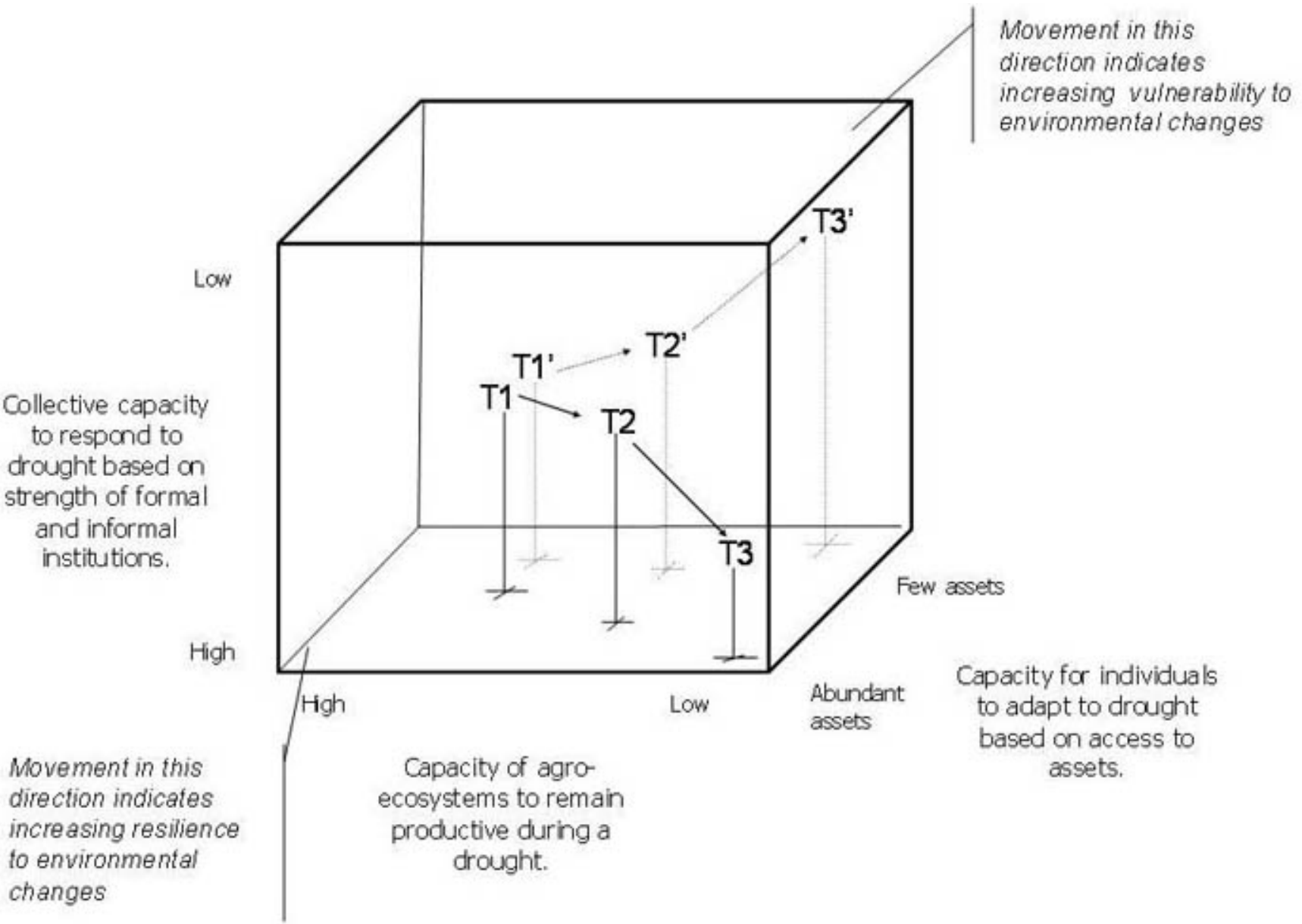

withstand the full rigor of academic analysis. However, there is a need for some scenario forecasting based on best available knowledge even though the datasets required to make realistic projections remain many years away across subSaharan Africa (Thompson and Scoones 2009). However, it is important to go through these mathematical steps, using best available estimates, to enable quantification of future scenarios.

We used both expert opinion, local stakeholder insights, from the iterations of interviews, and analysis of livestock offtake data obtained at district, village, and ranch scales (Reed and Dougill 2008; Fig. 4) to determine which of the relationships were positive or negative (Fig. 2) and their relative strengths for scenario modeling. For example, it was possible to trace changes in livestock offtake to changes in land ownership at a local village or ranch scale, and to assess existing relations between rainfall trends and offtake for different management types and ecological changes through time. We used this mix of expert insight and yield analysis to determine if relationships were linear, a sigmoid, or 
if they follow a u-shaped path, and made estimates as to the slope of the different relationships. We then used these assumptions as the basis for a series of hypotheses and expressed these as simple equations that posited how each variable was related. Only once the model was expressed in this way, did we run a baseline scenario and different policy, management, and market scenarios to see how the vulnerability to drought was sensitive to different interventions.

In all, we developed four different scenarios based on: (1) projected levels of climate change; (2) the effects of agricultural management in reducing rates of land degradation; (3) the effect of a government policy that slows the rate at which communal land is privatized; and (4) the effects of changes in the price for cattle. Each of these four scenarios was parameterized by creating a "best-case" and a "worst-case" situation that reflected the range of conditions deemed likely from the literature (Table 1). These best-and-worst case variants of each scenario were combined, giving 16 variants using the VENSIM software. The combinations of climate, land management, market, and policy scenarios provide a range of plausible futures that allow modeling of how overall system behavior changes in response to these factors. We stress that these remain only sketchily checked in relation to economic yield data because of the limitations in the quality of this data (Fig. 4). In particular, cattle statistics nationally and price statistics across southern Africa (FAO 2009) show huge interannual variability that is hard to capture in simplified market price scenarios at a coarse scale.

It is also important to note that even with this scenario-based approach, it was not possible to express all the possible relations using mathematical functions. In some cases, our confidence in data was weak. In other cases, the factors were inherently qualitative. In particular, we found it impossible to quantify institutional/collective aspects of vulnerability (y-axis on Fig. 3). As such, this research focused on changes to income based on herd size changes, a proxy for the individual's ability to adapt to drought, on a regional scale. Such analysis cannot account for the wider social, cultural, and biodiversity effects of changes in land ownership that have been highlighted by many assessing the shift to greater private land tenure across the Kalahari (see Sporton and Thomas 2002).

\section{Part II: Where are leverage points that could reduce vulnerability?}

Illustrative outputs from the dynamic systems model under modeled scenarios are separated to show the effects of different management scenarios (Fig. 5), market scenarios (Fig. 6), and policy options (Fig. 7). Figures 5 and 6 display the modeled outputs, over 100 model iterations / years, for the relative economic output from the total value of cattle held on private land (Figs. 5A and 6A) and on communal land (Figs. 5B and 6B) under different degradation and climate change scenarios under the rate of land conversion seen today. Finally, Figure 7 displays the effect on the total relative value of cattle on private and communal lands that would result from changes in the rate of land tenure conversion from communal to private ownership.

In our assessments of these modeled future scenarios, the following key implications are drawn from the modeled outputs within the confines of our selected variables:

- The effects of climate change, as per predictions of the Intergovernmental Panel on Climate Change (IPCC), have the largest economic impact on the future value and economic viability of pastoral systems. As such, efforts at the local and regional level will not have as large an economic effect as global influences of future climatic changes, notably desiccation of the semiarid system as predicted by regionally downscaled climate models (e.g., Thomas et al. 2005, Hewitson and Crane 2006).

- The positive benefits of improved management, guided by holistic rangeland management guides (Tainton 1999, Reed and Dougill 2010), are apparent under all cases. The extent of the 'best' management impacts are greatest under private land ownership and for the first 20 years of modeled iterations showing that this is capable of absorbing much of the economic effects associated with climate change (Fig. 5A).

- Market growth scenarios would not be sufficient to alleviate the economic losses seen from the communal sector associated with continued rapid rates of land conversion to private ownership (Fig. 6B). As such, 
Fig. 4. Communal land livestock holdings for A) an example 10 villages in Southern Kgalagadi District and B) Southern Kgalagadi District. Source: Republic of Botswana, Department of Agriculture Statsitics, Gaborone.

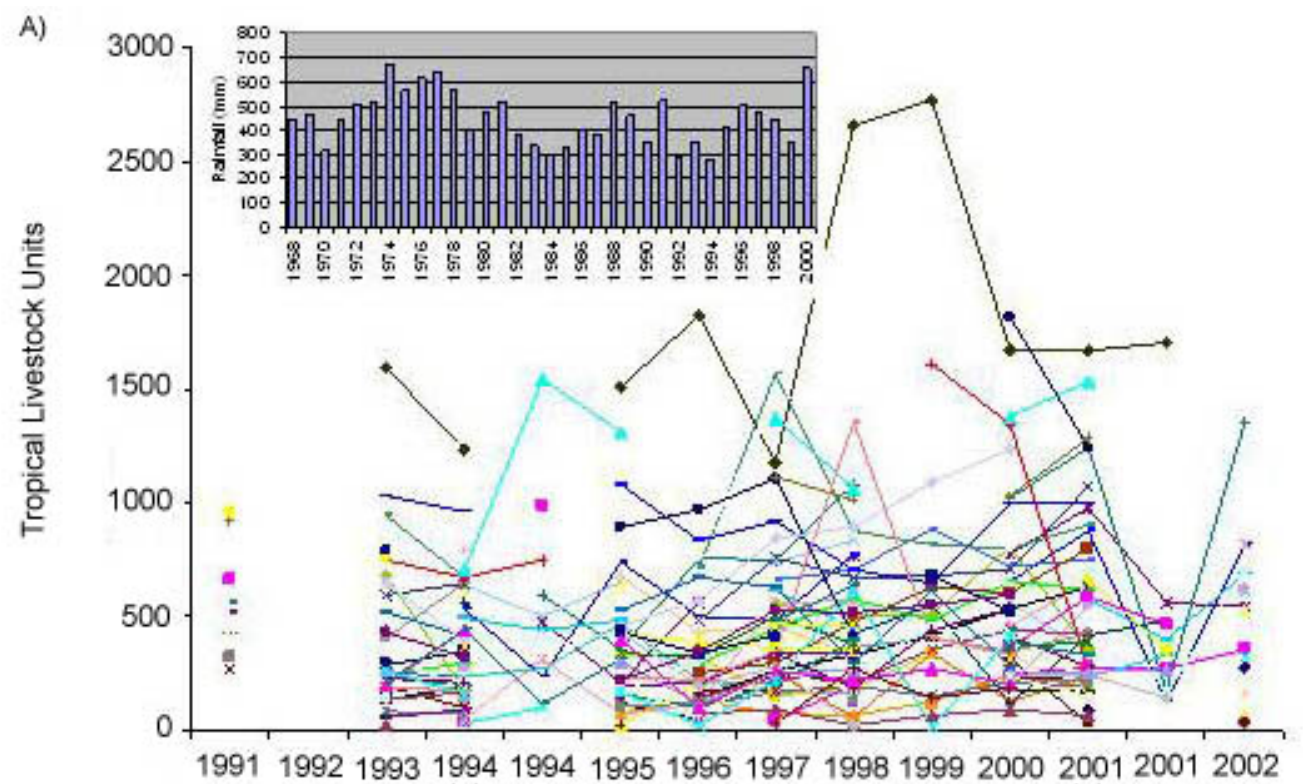

(a) (b)

(a) (b)

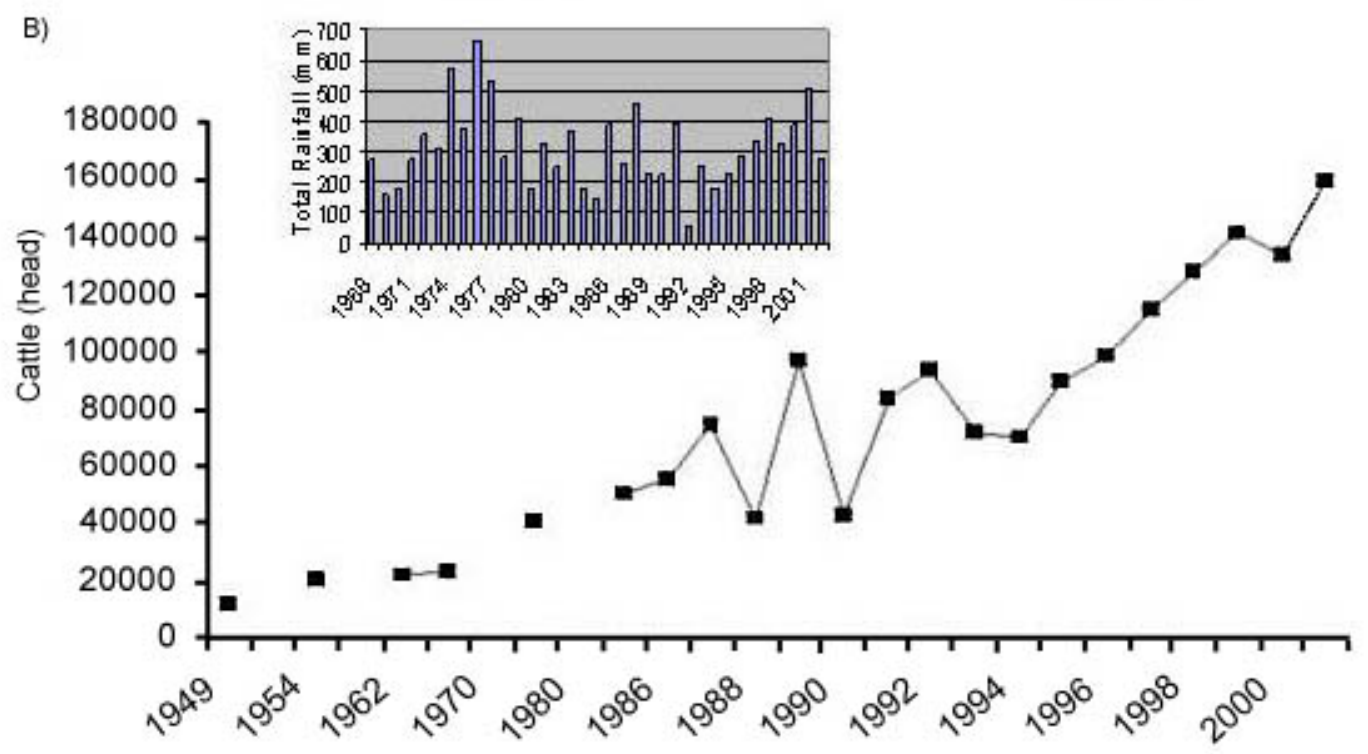


Table 1. Summary of scenarios developed to quantify relative effect of different drivers on the value of cattle herd for private and communal herders in southern Botswana. The key references used to parameterize the scenarios are: (1) Christensen et al. 2007; (2) Quan et al. 1994, Reed and Dougill 2008; (3) Dougill et al. 1999 ; (4) Adams et al. 1999 ; (5) Adams 2001; (6) FAO 2006, Perrings and Stern 2000.

\begin{tabular}{|c|c|c|c|}
\hline $\begin{array}{l}\text { Scenario } \\
\text { name }\end{array}$ & Description & Lower estimates & Upper estimates \\
\hline $\begin{array}{l}\text { Climate } \\
\text { change }\end{array}$ & $\begin{array}{l}\text { This scenario determines what } \\
\text { effect climate change has on the } \\
\text { value of communal and private } \\
\text { cattle herds and is based on IPCC } \\
\text { rainfall projections and historical } \\
\text { analysis of rainfall variability. }\end{array}$ & $\begin{array}{l}40 \% \text { interannual variability and no } \\
\text { long-term change in rainfall. }{ }^{1}\end{array}$ & $\begin{array}{l}40 \% \text { interannual variability and a } \\
0.1 \% \text { p.a. decline in average } \\
\text { rainfall. }{ }^{1}\end{array}$ \\
\hline $\begin{array}{l}\text { Environmental } \\
\text { management }\end{array}$ & $\begin{array}{l}\text { This scenario determines to what } \\
\text { extent best agricultural } \\
\text { management practices might } \\
\text { reduce the effects of bush } \\
\text { encroachment and is based on the } \\
\text { ecological literature on the effects } \\
\text { of bush encroachment. }\end{array}$ & $\begin{array}{l}\text { Improved management leads to } \\
\text { increases of } 1 \% \text { p.a. for a period } \\
\text { of } 10 \text { years on private land, } \\
\text { whereas improved management } \\
\text { on communal land leads to } \\
\text { increases of } 0.1 \% \text { p.a. for a period } \\
\text { of } 20 \text { years } 2 \text {. }\end{array}$ & $\begin{array}{l}\text { Bush encroachment leads to a } \\
0.05 \% \text { p.a. decline over the full } \\
\text { model run period for both private } \\
\text { and communal herders. }{ }^{3}\end{array}$ \\
\hline $\begin{array}{l}\text { Land tenure } \\
\text { policy }\end{array}$ & $\begin{array}{l}\text { This scenario simulates the effects } \\
\text { of a governmental policy that slows } \\
\text { the rate at which communal land is } \\
\text { privatized and is based on the } \\
\text { effects of similar policy in } \\
\text { neighboring countries. }\end{array}$ & $\begin{array}{l}\text { A 'slow conversion' rate from } \\
\text { communal to private ownership of } \\
0.1 \% \text { p.a. based on Botswana's } \\
\text { relatively high proportion of } \\
\text { "tribal" lands compared with } \\
\text { neighboring countries. }\end{array}$ & $\begin{array}{l}0.5 \% \text { p.a. of communal land is } \\
\text { privatized based on high rates of } \\
\text { private land holdings in } \\
\text { neighboring countries. }\end{array}$ \\
\hline $\begin{array}{l}\text { Market } \\
\text { conditions }\end{array}$ & $\begin{array}{l}\text { This scenario determines how } \\
\text { changes in the price of cattle may } \\
\text { affect the value of communal and } \\
\text { private cattle herds and is based on } \\
\text { long term cattle price trends. }\end{array}$ & $\begin{array}{l}0.05 \% \text { p. a. increase in the price of } \\
\text { cattle could occur from greater } \\
\text { market access or higher market } \\
\text { prices (either internationally or } \\
\text { from greater national control / } \\
\text { price guarantees to pastoralists). }\end{array}$ & $\begin{array}{l}10 \% \text { annual variability in price but } \\
\text { no long-term changes because } \\
\text { historic analysis of price does not } \\
\text { show significant rises or falls in } \\
\text { adjusted cattle price over past } 40 \\
\text { years. }\end{array}$ \\
\hline
\end{tabular}

policy leverage to support market price rises for livestock would preferentially favor the private sector that is more efficient in producing cattle for sale on national and international markets (Fig. 6A). Such support would therefore not address the poverty alleviation needs of communal pastoralists.

- Policy interventions aimed at changing the rate of land conversion from communal to private land ownership when assessed in a solely economic manner display that continued rapid rates of land privatization can help to increase the overall value of cattle regionally and buffer some of the effects of climate change and/or degradation (Fig. 7).
When assessing these modeled outputs, it is important to note that they only display the predicted economic effects of different scenarios solely for the pastoral system and not the more diversified livelihood options practiced. As such, these model outputs fail to capture important effects on social capital, community cohesion, equality and/or poverty levels, and biodiversity or carbon storage declines that have important economic value and implications, but which remain difficult to feed into policy-making nationally. The need to value these broader ecosystem services is a vital next step required for research in this region, as in other drylands (Turner and Daily 2008). It is also important to note that results remain far from 
Fig. 5. Management scenario options and their impacts on the value of cattle on A) private land and B) communal land across Southern Botswana (as per scenario assumptions in Table 1).
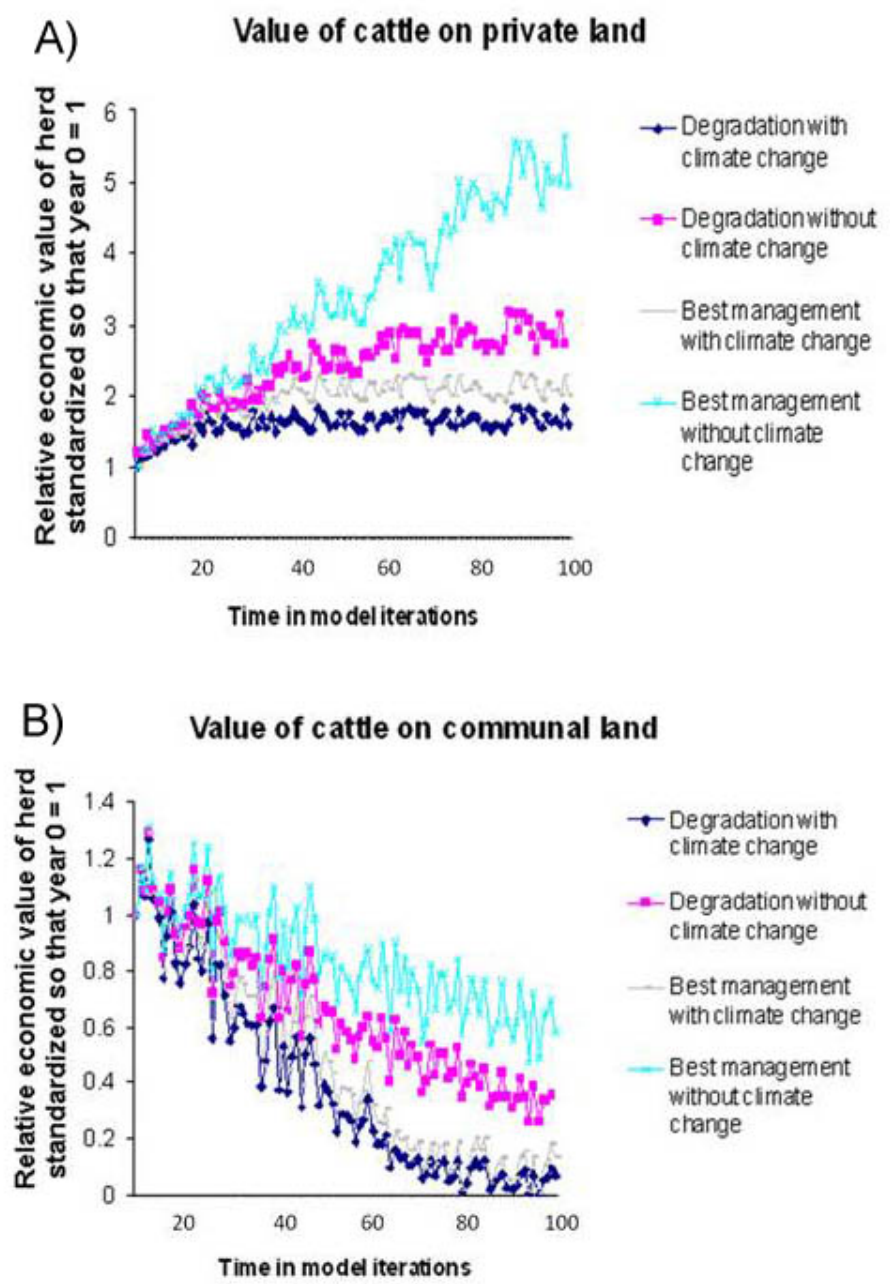

definitive, because of the problems of data parameterization of models given the limited quantitative livestock data available. Therefore, these results should be treated as hypotheses requiring further testing and as a guide to focus future research design rather than as firm conclusions. As such, before any policies are developed, there needs to be a further empirical research involving local scale quantitative yield assessments to test the validity of these claims.

\section{DISCUSSION}

We provide an extension of farming systems research that is based on field data into a dynamic conceptual model and then a quantitative dynamic system model informed by livestock yield data. The quantitative scenario-based approach has the potential to enhance the communicative power of vulnerability assessments including the graphical representation of economic effects of different management, market, and policy futures (Figs. 5-7). In following such a quantitative approach, we can provide further insights into the farming system under consideration, in terms of factors affecting its 
Fig. 6. Market scenario options and their impacts on the value of cattle on A) private land and B) communal land across Southern Botswana (as per scenario assumptions in Table 1).
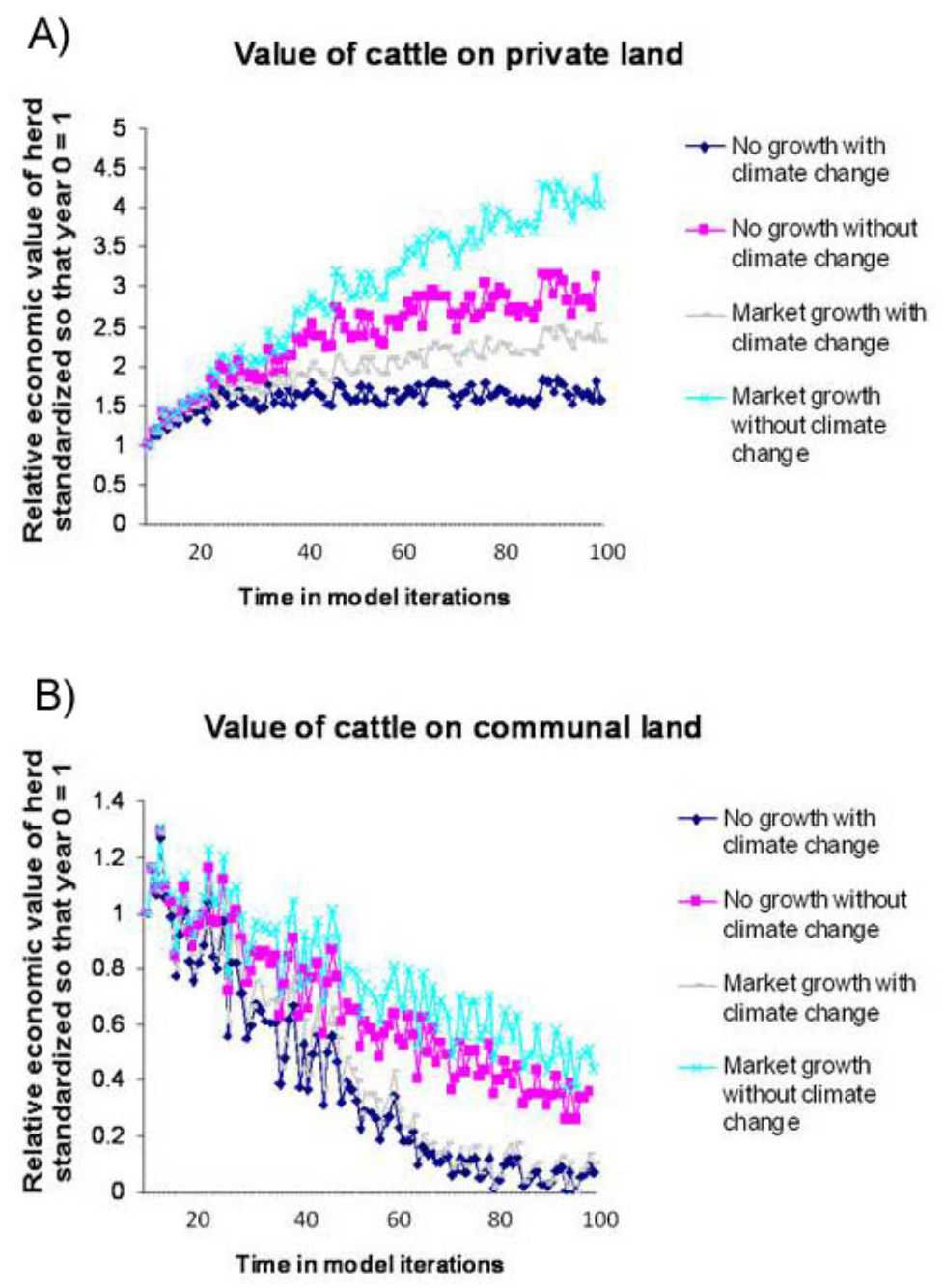

vulnerability to future droughts. In particular, we highlight the following empirical findings:

1. Cattle herds and associated incomes are likely to continue declining in communal lands under most scenarios. This is due to the effects of ongoing land degradation and will be exacerbated by climate change and fast rates of land tenure conversion to private ownership. Improvements in rangeland management practices are, as yet, only making small improvements to the income that can be derived from communal herds.
One way to view such findings is that further land privatization will help enhance national income but needs to be complemented with support directed at communal area residents. However, when combined with field research from communal rangelands (e.g., Reed et al. 2007, Sallu et al. 2009), the potential for learning about management practices, e.g., mix of cattle breeds, rotational grazing, controlled burning, and drought feed supplements, offers a route to improving livestock yields from communal lands and enhancing system resilience. Adopting bestpractices on communal lands will require 
Fig. 7. Policy scenario options and their impacts on the value of cattle on A) private land and B) communal land across Southern Botswana (as per scenario assumptions in Table 1).
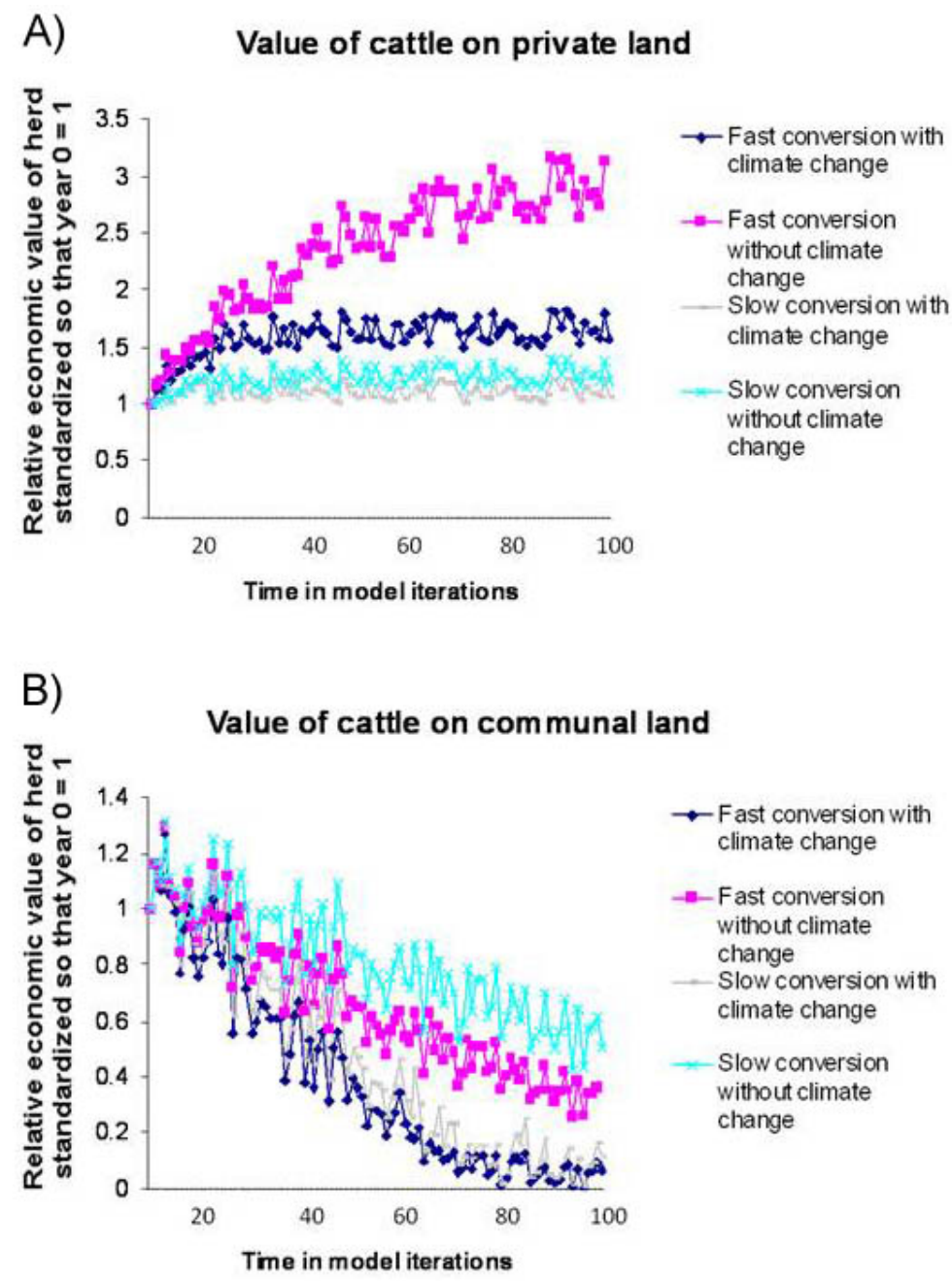

community-based management at a village level to provide wider social, cultural, and economic benefits in other dryland pastoral regions (e.g., Klintenberg et al. 2007, Oba et al. 2008). Empowering village level committees thus should be a priority to enable 'win-win-win' benefits that could span environmental, economic, and societal aspects of the dryland pastoral system.

2. Differences in the factors affecting the magnitude of future livestock income and/or offtake projections for private and communal lands further stresses the need to treat these as different farming systems (Thomas and Twyman 2004), even though they share the same climatic and ecological settings. The vulnerability pathway mapping (Fig. 3) enables us to generalize factors contributing toward the vulnerability pathways of each land tenure system, which is useful for identifying policy leverage points and likely effects. By linking dynamic system models with ecological state and transition models it will be possible to explore causes and timings of thresholds that control system vulnerability to droughts. 
3. A final indicative finding is the portrayal of the greater effect that global climate change and international market drivers have compared with improvements in land management practices. Although long-term benefits have been shown from local-level shifts in grazing management practices (Reed and Dougill 2010), the lack of immediacy and limited extent to which this benefits income explains some of the difficulties in encouraging changes to management practices (Reed et al. 2008).

In terms of policy guidance aimed at developing projects or policy at the district or national level to reduce vulnerability to climate change, our analysis suggests:

1. There remains a need for greater encouragement of, and support for, improved rangeland management approaches, notably in sharing lessons between management practices from private ranches to communal rangelands. Improved rangeland management involves better matching of grazing intensities with fodder availability (e.g., Joubert et al. 2008). This may result from either local-scale rotational grazing practices or district level schemes to support landscapescale movement of cattle in response to changes in fodder availability. Such regional movements have long typified the Kalahari pastoralists drought coping strategies and is formalized traditionally through the mafisa livestock movement system, in which friends and family exchange livestock over hundreds of kilometers, enabling herds to track forage resources at a landscape scale. This would require the introduction of improved national marketing systems to facilitate rapid destocking at the onset of drought as seen in Namibia (Katjiua and Ward 2007). Barriers include the increasing numbers of absentee livestock owners (Perkins 1996) and continued privatization of communal areas that reduces the extent of traditional grazing reserves during drought (Twyman et al. 2002).

2. A combination of land privatization, together with the establishment and empowerment of formal communal village committees and market price increases, represents the most significant opportunities to sustainably increase herds and incomes (Fig. 6A), and hence reduce the vulnerability of the system to future climate change. In this regard, the more nuanced portrayal of vulnerability pathways provided here and the risks of increasing vulnerability in both private and communal systems provide guidance on routes to reduce vulnerability.

3. Increasing market accessibility at the household, community, or private ranch level, will increase incomes obtained from the farming system as a whole, and will not increase the system vulnerability to droughts. This is especially true for communal systems, in which it would be beneficial for the government to focus on providing the routes to market, via the Botswana Meat Corporation, in as fair and equitable a manner as possible. Such a shift would enable sharing of the benefits currently seen on private land to communal rangelands. Experiences from the establishment of ranch-owning syndicates and from communities where communitybased rangeland management initiatives have taken root firmly (e.g., the Namibian case outlined in Klintenberg et al. 2007) suggest that such community-wide mechanisms offer a route to enable economic gains, while avoiding many of the equality and marginalization concerns with the move away from communal ownership.

4. The enhanced support of local extension services, and their ability to outline the longterm benefits of improvements in agricultural management practices such as those in locally-developed management guides, is essential in realizing the benefits that shifts in agricultural practice can lead to. This is especially so in the face of significant additional economic and environmental pressures associated with regional climate change predictions.

Finally, we re-emphasize that this policy guidance is based on a model created from expert judgments and preliminary economic appraisals only. As such, the findings reflect the biases and assumptions of those who built the model and the limited data available to parameterize this information. Representing these judgments mathematically is controversial because numerical outputs can give 
an illusion of certainty and authority that may be misleading. We stress that dynamic systems modeling offers a rapid, transparent, and systematic approach to capture and use expert knowledge to understand how complex systems might work. In contrast to the way quantitative models from the reductionist school are communicated with errorbounded certainty, dynamic systems models fit more comfortably in an interpretivist school, where there are different interpretations by different people in different contexts. In this context, rather than shying away from quantifying models based on expert opinion, this paper uses the heuristic power of a tool from which both researchers and decision makers can learn.

In terms of the theoretical contribution this research has made to vulnerability debates, key insights from this case study include:

1. Reanalyzing data using a predetermined framework has allowed us to highlight vulnerability pathways (Fig. 3) that can then be quantified (Figs. 5-7) to allow for comparability with qualitative field-based research.

2. The hypothesis that there may be generic vulnerability trajectories that are common to a range of different situations and that common policy strategies may be suitable for each type of trajectory.

3. In terms of developing the mathematical formulae in the dynamic systems models, we feel that this approach has merits in that it created a visual representation that allows the explanation of system behavior. The act of programming the dynamic system was also useful in exposing and quantifying the assumptions we made in the narrative and scenario building (Table 1).

\section{CONCLUSIONS}

This research increases our understanding of dryland pastoral systems and how they are vulnerable to climate change using reflections and reanalysis of a substantive body of research from across the Kalahari. The largest threat to the economic viability of the pastoral food system is shown as regional climate change, highlighting that all routes to enhance resilience to future droughts must be considered seriously. The qualitative aspect of our analysis shows that government land privatization policy has helped wealthier ranchers, but has increased the vulnerability of poorer communal pastoralists (Fig. 3). Privatization does, however, remain a route to enhance resilience at a national and district scale as the wealthier, private land-owning group has become less vulnerable to drought, because of this group's ability to purchase food and leverage help from institutions (Chanda et al. 2003) and to undertake a wider range of management options. Poorer communal pastoralists, however, have lost assets and experienced significant rangeland degradation. Their vulnerability to drought has increased so that even small droughts can have larger livelihood impacts.

The quantitative aspect of our analysis suggests that increasing access to markets and improving the access and empowerment of poorer communal farmers, through community-based management committees or formal syndicates, can reduce system vulnerability more than programs designed to improve land management within 'loose' communal land management structures. Greater sharing of management knowledge and practices between private and communal land owners offers the best opportunity for 'win-win' benefits of reduced system vulnerability and redressing some of the inequalities in poverty and livelihood status across the Kalahari. The achievement of this will involve formalization of management structures at a village level, community engagement in developing and using locally appropriate rangeland monitoring and evaluation tools, and institutional support to empower community groups to function both for the community and among communities. This would allow community groups to share knowledge and allow livestock movements in response to fodder availability patterns as required for efficient use of dryland fodder resources.

Responses to this article can be read online at: http://www.ecologyandsociety.org/vol15/iss2/art17/ responses/ 


\section{LITERATURE CITED}

Adams, M. 2001. Tenure security, livelihoods and sustainable land use in Southern Africa. SARPN Conference on Land Reform and Poverty Alleviation in Southern Africa. [online] URL: http: //www.sarpn.org.za/EventPapers/Land/20010604Adams. pdf.

Adams, M., S. Sibanda, and S. Turner. 1999. Land tenure reform and rural livelihoods in Southern Africa. ODI Natural resource perspectives 39. Overseas Development Institute, London, UK.

Adams, M., R. White, N. Raditloaneng, M. Aliber, G. Stracey, C. McVey, F. Kalabamu, P. McAuslan, N. Kgengwenyane, C. Sharp, and B. Egner. 2002. National land policy: issues report. Republic of Botswana, Ministry of Lands, Housing and Environment, Department of Lands, Natural Resource Services (Pty) Ltd, Gaborone, Republic of Botswana.

Botswana Department of Environmental Affairs. 2006. Botswana national action programme to combat desertification. Department of Environmental Affairs, Ministry of Wildlife and Tourism, Gaborone, Republic of Botswana.

Berkeley, A., A. D. Thomas, and A. J. Dougill. 2005. Spatial dynamics of biological soil crusts: bush canopies, litter and burial in Kalahari rangelands. African Journal of Ecology 43:137-145.

Bhalotra, Y. P. R. 1987. Climate of Botswana. Part II. Elements of climate. 1. Rainfall. Department of Meteorological Services, Republic of Botswana.

Chanda, R., O. Totolo, N. Moleele, M. Setshogo, and S. Mosweu. 2003. Prospects for subsistence livelihood and environmental sustainability along the Kalahari transect: the case of Matsheng in Botswana's Kalahari rangelands. Journal of Arid Environments 54:425-445.

Chipanshi,A. C., R. Chanda, and O. Totolo. 2003. Vulnerability assessment of the maize and sorghum crops to climate change in Botswana. Climatic Change 61:339-360.

Christensen, J. H., B. Hewitson, A. Busuioc, A. Chen, X. Gao, I. Held, R. Jones, R. K. Kolli, W.T. Kwon, R. Laprise, V. Magaña Rueda, L. Mearns, C. G. Menéndez, J. Räisänen, A. Rinke, A. Sarr, and P. Whetton. 2007. Regional climate projections. In S. Solomon, D. Quin, M. Manning, Z. Chen, M. Marquis, K. B. Averyt, M. Tignor and H. L. Miller, editors. Climate change 2007: The Physical Science Basis. Contribution of Working Group I to the Fourth Assessment Report of the Intergovernmental Panel on Climate Change. Cambridge University Press, Cambridge, UK.

Central Intelligence Agency (CIA). 2009. The world factbook: Botswana. [online] URL: https://w ww.cia.gov/library/publications/the-world-factbook/ geos/bc.html.

Clover, J., and S. Eriksen. 2009. The effects of land tenure on sustainability: human security and environmental change in southern African savannas. Environmental Science and Policy 12:53-70.

Dougill, A. J., D. S. G. Thomas, and A. L. Heathwaite. 1999. Environmental change in the Kalahari: integrated land degradation studies for noneqilibrium dryland environments. Annals of the Association of American Geographers 89:420-442.

Dougill, A. J. 2002. Ecological change in Kalahari rangelands: permanent or reversible? Pages 91-110 in D. Sporton and D. S. G. Thomas, editors. Sustainable livelihoods in Kalahari environments: contributions to global debates. Oxford University Press, Oxford, UK.

Dougill, A. J., C. Twyman, D. S. G. Thomas, and D. Sporton. 2002. Soil degradation assessment in mixed farming systems of Southern Africa: use of nutrient balance studies for participatory degradation monitoring. Geographical Journal 168:195-210.

Food and Agriculture Organization of the United Nations (FAO). 2006. The state of food insecurity in the world 2006. Food and Agriculture Organization of the United Nations, Rome, Italy.

Food and Agriculture Organization of the United Nations (FAO). 2009. [online] URL: http://faostat. fao.org.

Fraser, E. D. G. 2007. Travelling in antique lands: studying past famines to understand present vulnerabilities to climate change. Climate Change 83:495-514.

Hewitson, B. C., and R. G. Crane. 2006. Consensus between GCM climate change projections with empirical downscaling: precipitation 
downscaling over South Africa. International Journal of Climatology 26:1315-1337.

Hitchcock, R. K. 2002. Coping with uncertainty: adaptive responses to drought and livestock disease in the northern Kalahari. Pages 221-236 in D. Sporton and D. S. G. Thomas, editors. Sustainable livelihoods in Kalahari environments: contributions to global debates. Oxford University Press, Oxford, UK.

Intergovernmental Panel on Climate Change (IPCC). 2007. Climate change 2007: impacts, adaptation and vulnerability. M. Parry, O. Canziani, J. Palutikof, P. van der Linden, and C. Hanson, editors. Working Group II contribution to the Fourth Assessment Report of the Intergovernmental Panel on Climate Change. Cambridge University Press, Cambridge, UK.

Joubert, D. F., A. Rothauge, and G. N. Smit. 2008. A conceptual model of vegetation dynamics in the semiarid Highland savanna of Namibia, with particular reference to bush thickening by Acacia mellifera. Journal of Arid Environments 72:2201-2210.

Katjiua, M., and D. Ward. 2007. Pastoralists' perception and realities of vegetation change and browse consumption in the northern Kalahari, Namibia. Journal of Arid Environments 69:716-730.

Klintenberg, P., M. K. Seely, and C. Christiansson. 2007. Local and national perceptions of environmental change in central northern Namibia: Do they correspond? Journal of Arid Environments 69:506-525.

Lane, C. R. 1997. Custodians of the commons. Pastoral land tenure in East and West Africa. Earthscan, London, UK.

McGranahan, D. A. 2008. Managing private, commercial rangelands for agricultural production and wildlife diversity in Namibia and Zambia. Biodiversity and Conservation 17:1965-1977.

Milton, S. J., W. R. J. Dean, and D. M. Richardson. 2003. Economic incentives for restoring natural capital in southern African rangelands. Frontiers in Ecology and Environment 1:247-254.
Moleele, N. M., S. Ringrose, W. Matheson, and C. Vanderpost. 2002. More woody plants? The status of bush encroachment in Botswana's grazing areas. Journal of Environmental Management 64:3-11.

Oba, G., E. Sjaastad, and H. G. Roba. 2008. Framework for participatory assessments and implementation of global environmental conventions at the community level. Land Degradation and Development 19:65-76.

Parry, M., C. Rosenzweig, A. Iglesias, G. Fischer, and M. Livermore. 1999. Climate change and world food security: a new assessment. Global Environmental Change 9:S51-S67.

Perkins, J. S. 1996. Botswana: fencing out the equity issue. Cattleposts and cattle ranching in the Kalahari Desert. Journal of Arid Environments 33:503-517.

Perrings, C., and D. I. Stern. 2000. Modelling loss of resilience of agroecosystems: rangelands in Botswana. Environmental and Resource Economics 16:185-210.

Quan, J., D. Barton, and C. Conroy. 1994. A preliminary assessment of the economic impact of desertification in Namibia. Directorate of Environmental Affairs Research Discussion Paper 3, Ministry of Environment and Tourism, Republic of Namibia.

Reed, M. S., and A. J. Dougill. 2008. Participatory land degradation assessment. Pages 719-729 in C. Lee and T. Schaaf, editors. The Future of Drylands. UNESCO, Paris, France and Springer, Berlin, Germany.

Reed, M. S., and A. J. Dougill. 2010. Linking degradation assessment to sustainable land management: a decision support system for Kalahari pastoralists. Journal of Arid Environments 74:149-155.

Reed, M. S., A. J. Dougill, and T. R. Baker. 2008. Participatory indicator development: What can ecologists and local communities learn from each other? Ecological Applications 18:1253-1269. 
Reed, M. S., A. J. Dougill, and M. J. Taylor. 2007. Integrating local and scientific knowledge for adaptation to land degradation: Kalahari rangeland management options. Land Degradation and Development 17:1-19.

Reynolds, J. F., D. M. Stafford-Smith, E. F. Lambin, B. L. Turner, M. Mortimore, S. P. J. Batterbury, T. E. Downing, H. Dowlatabadi, R. J. Fernandez, J. E. Herrick, E. Huber-Sannwald, H. Jiang, R. Leemans, T. Lynam, F. T. Maestre, M. Ayarza, and B. Walker. 2007. Global desertification: building a science for dryland development. Science 316:847-851.

Ringrose, S., R. Chanda, M. Nkambwe, and F. Sefe. 1996. Environmental change in the mid-Boteti area of north-central Botswana: biophysical processes and human perceptions. Environmental Management 20:397-410.

Rohde, R. F., N. M. Moleele, M. Mphale, N. Allsopp, R. Chanda, M. T. Hoffmann, L. Magole, and E. Young. 2006. Dynamics of grazing policy and practice: environmental and social impacts in three communal areas of southern Africa. Environmental Science and Policy 9:302-316.

Sallu, S. M., C. Twyman, and D. S. G. Thomas. 2009. The multidimensional nature of biodiversity and social dynamics and implications for contemporary rural livelihoods in remote Kalahari settlements, Botswana. African Journal of Ecology 47:110-118.

Sporton, D., and D. S. G. Thomas. 2002. Sustainable livelihoods in Kalahari environments: contributions to global debates. Oxford University Press, Oxford, UK.

Stringer, L. C., M. S. Reed, A. J. Dougill, M. K. Seely, and M. Rokitzki. 2007. Implementing the UNCCD: participatory challenges. Natural Resources Forum 31:198-211.

Tainton, N. M. 1999. Veld management in South Africa. University of Natal Press, Pietmaritzburg, South Africa.

Tennant, W. J., and B. C. Hewitson. 2002. Intraseasonal rainfall characteristics and their importance to the seasonal prediction problem. International Journal of Climatology 22:1033-1048.
Thomas, D. S. G., M. Knight, and G. F. S. Wiggs. 2005. Remobilization of southern African desert dune systems by twenty-first century global warming. Nature 435:1218-1221.

Thomas, D. S. G., D. Sporton, and J. S. Perkins. 2000. The environmental impact of livestock ranches in the Kalahari, Botswana: natural resource use, ecological change and human response in a dynamic dryland system. Land Degradation and Development 11:327-341.

Thomas, D. S. G., and C. Twyman. 2004. Good or bad rangeland? Hybrid knowledge, science and local understandings of vegetation dynamics in the Kalahari. Land Degradation and Development 15:215-231.

Thompson, J., and I. Scoones. 2009. Addressing the dynamics of agri-food systems: an emerging agenda for social science research. Environmental Science and Policy 12:386-397.

Toulmin, C., and J. Quan. 2000. Evolving land rights, policy and tenure in Africa. Department for International Development Issues Series: International Institute for Environment and Development and Natural Resources Institute, London, UK.

Turner R. K., and G. C. Daily. 2008. The ecosystem services framework and natural capital conservation. Environmental and Resource Economics 39:25-35.

Twyman, C., A. J. Dougill, D. Sporton, and D. S. G. Thomas. 2002. Community fencing in open rangelands: a case study of community selfempowerment in Eastern Namibia. Review of African Political Economy 28:9-26.

Twyman, C., D. Sporton, and D. S. G. Thomas. 2004. 'Where is the life in farming?': The viability of smallholder farming on the margins of the Kalahari, Southern Africa. Geoforum 35:69-85.

Warren, A. 2002. Land degradation is contextual. Land Degradation and Development 13:449-459.

Washington, R., T. E. Downing, M. New, G. Ziervogel, S. Bharwani, and M. Bithell. 2005. Climate outlooks and agent-based simulation of adaptation in Africa. Tyndall Centre for Climate Change Research Report T2.32. University of East Anglia, Norwich, UK. 
White, R. 1993. Livestock development and pastoral production on communal rangeland in Botswana. The Botswana Society, Gaborone, Republic of Botswana. 